\title{
AESTHETIC FREEDOM IN GROUNDWORK FOR THE METAPHYSICS OF MORALS AND THE CRITIQUE OF THE POWER OF JUDGMENT
}

\author{
By Thomas Cook
}

The impetus for this paper began in a seminar I'm currently enrolled in this semester at Albany, Politics in Poetry. In this seminar I've been considering various relations between the political and the aesthetic. During the course of the seminar I've found the ways we articulate the various relations between the political and the aesthetic to be not only complicated, but infinitely more difficult to discuss when we've proceeded by way of a close reading of a particular poem, poet, or statement of poetics. The two most reductive shortcuts to an analysis of the political and the aesthetic go as follows:

\section{The political is necessarily synonymous with the aesthetic.}

For example, when I discuss diction, enjambment, style, form, even publication history, I am simultaneously discussing aesthetics and politics. This reduction typically relies on a few ideas:

1. Language is inherently political so each word I use is politically charged. As I build or read a poem I am assembling a politics. This idea seems to value a kind of materialistic structural linguistic model.

2. Artistic expression is inherently a political act. This idea conflates lyric expression with political activism or at least agency. The narcissistic loop suggests that if society is not changed by the poem or the poet, the poet herself is changed. 
3. The status of poetry and art in society is a symptom of political conditions. In short, politics and aesthetics are conflated and their terms are intermingled.

\section{The second reduction involves an insistence that the aesthetic and the political are separate.}

Historically, their discourses overlap and include many of the same authors and texts, however the relationship between the two requires an explicit effort on behalf of one (poet, politician, radical, head of state, anarchist) to engage the other. In short, they are separate realms which are attracted to one another but are not synonymous. They are in contact or periphery to one another.

The recourse to these two larger, reductive forms of analysis has left me with series of questions regarding the way aesthetics and politics are often thought of in relation to poetry, the act of writing poetry, and the instruction of poetry. I believe appropriately these questions have lead me back to Kant and to the formalization his aesthetic and moral theory in the "Doctrine of the Right” contained in The Metaphysics of Morals and, “The Critique of Aesthetic Judgment” in The Critique of Judgment.

Naturally, the first question you might have for me is, what could a poet possibly want to do with Kant? My reading of the "Doctrine of the Right" is undertaken with the general hypothesis that after the third critique, though Kant purported and intended to begin on a doctrinal set of works that include his moral philosophy and and his anthropology among others, his tendency to focus on aesthetic judgment in his later works (particularly The Metaphysics of Morals and Anthropology From a Pragmatic Point of View), underlies his basis for moral and political philosophy and the formation of subjectivity. For these reasons, Kant provides a doctrine we can look to for a coherent theory of how aesthetics and politics are related. Kant approaches his politics through "feeling." 
Kant begins the "Doctrine of the Right" considering desire. Our capacity for desire, Kant writes, is our capacity to be "by means of representation the cause of our representations" ( $M M$ 122). "The Doctrine of the Right” follows as an explication of how to live our lives in a state of negotiation of our desires. "Life," Kant writes, "is to act in accordance with its representations" (MM 122). Insofar as an individual is the cause of his or her own representations, he or she may or may not be susceptible at the time of those representations, to feeling. Morality is predicated upon susceptibility to feeling and so is defined negatively in Kant's system. Morality is afloat in desire and we necessarily resist desires to define morality. By linking morality with resistance to feeling, Kant defines his morals aesthetically.

Susceptibility to feeling, the negotiation of which produces either moral, immoral, or amoral action, is the fundamental predicament of the human being. We cultivate either "desire" or "aversion" to representation we ourselves are the cause of based on the "pleasure" or "displeasure" the representations affect in us. The analog to the object of beauty in "The Critique of Aesthetic Judgement” is found in the fact that we can know nothing of the pleasure or displeasure which is affected in us by the representation we represent to ourselves because in "The Doctrine of the Right” our sensations of pleasure and displeasure "are still referred to an object as elements in our knowledge of it" and they express "nothing at all in the object but simply a relation to the subject. For this reason pleasure and displeasure cannot be explained more clearly in themselves; instead, one can only specify what results they have in certain circumstances, so as to make them recognizable in practice” ( $M M$ 212). Appropriately, then, this definition of the object of desire and it's relation to feeling takes place externally. Externality is the only true realm of Freedom for Kant. True Freedom, what is Right cannot be referred to moral or juridical law. It must instead by a external both physically and reflectively. we cannot 
refer a free choice to our moral sense or a body of laws.

Freedom is our "only innate right” in Kant's system, and freedom is linked to choice insofar as it is defined as independence from being constrained by another's choice” ( $M M$ 63). Innate freedom has three constituent parts:

"Equality, which Kant defines as "Independence form being bound by others more than one can in turn bind them the ability to be 'one's own master (sui iuris)'”

what roughly equates to freedom of speech or action as long as that speech or act does not impede the freedom of others (MM 63).

In his book, Force and Freedom, which is a study of Kant's legal and political philosophy published last year, Arthur Ripstein appropriately radicalizes the idea of freedom in Kant, and he puts it in action. This action has aesthetic consequences and relates back to the third critique. First, Ripstein notes that “Interference with another person’s freedom creates a form of dependence; independence requires that one person not be subject to another person's choice. Kant's account of independence contrasts with more robust conceptions of autonomy, which sometimes represent it as a feature of a particular agent. On this conception, if there were only one person in the world, it makes sense to ask whether and to what extent that person was autonomous. Kantian independence is not a feature of the individual person in isolation, but of relations between persons” (Ripstein 15). Ripstein uses two examples to further investigate this.

One example, is the idea of vocational promotion. Let's say you are promoted at your business or place of work. Ripstein argues that if you are promoted, your freedom, your rights, and in turn what is Right is violated. Why? Because someone has chosen for you. Even if you desire the promotion, it is the desire of the one promoting that has affected external change in the world. Promotion is largely a violation of freedom. (Think for a second of how we are indebted, 
however benignly, to people who do nice things for us.) The only way a promotion would not be a violation of freedom would be if externally the promotion were a choice of both the promoter and the one being promoted. What would that look like? Perhaps it is impossible to see, or perhaps it is the way we naturally assume new roles within certain social and private structures without the unfreedom of a formal process. Kant's freedom creates a society where social structure may still exist, but they must be non-hierarchical, a kind of anarchism.

The other example Ripstein uses is the example of two individuals at the grocery store. Both individuals desire a gallon milk. There is unfortunately only one gallon of milk, however. The first individual grabs the milk and purchases it. The second individual cannot buy the milk. This, in Kant's thinking, is not a violation of freedom because although the individual who ended up with the milk happens to have deprived the other individual of milk, the individual with milk has not imposed any limits on the independence of the individual without milk capacity for freedom of choice. The individual without milk has actually, as a result of not buying milk at this store, experienced an increase in freedom, to choose to go and find milk elsewhere, to choose something other than milk entirely, or to choose something anterior to choosing milk at the store. For the individual who was unable to purchase the milk to consider not being able to purchase milk a violation of his or her innate freedom would be a shortcoming of that individual's capacity for freedom of choice. (In the former example, I might suggest that declining promotion is always in the interest of maintaing the greatest amount of freedom.)

Because true freedom of choice must be external, it cannot be strictly moral or juridical. If a free choice coincides with a moral or a juridical law it is not excluded from being a free choice, however it is more difficult to determine wherein the freedom lies. In poetry, specifically poetry that is read politically we must consider how choice determines our reaction to the poem 
and the role that poetry instruction plays in limiting poetry's freedom.

Once a poem is domesticated by means of a reading, wherein it's aesthetics are made political, the poem's ability to act with a freedom exemplary of the most innate political freedom is severely hindered. Once a a poem has been taught, it's innate freedom is in danger.

When Kant links the freedom of genius in the third critique to the pure productive capacity of nature, he writes that "nature gives the rule to art.” He laments that "one cannot learn to write inspired poetry however elaborate all the precepts of this art may be, and however superb its models” (309). Furthermore, he writes, “the artist’s skill cannot be communicated but must be conferred directly on each person by the hand of nature” (309). This externality finds its analog in political freedom.

Reading this passage from “The Critique of Aesthetic Judgment” alongside the passage from “The Doctrine of the Right” brings us back to considerations of political poetry and poetry as a whole. I ask these questions: Do you believe the political poet would hope for their work to be considered a statement on a political situation more than an actualized political reality? Would the political poet intend for his or her work to be seen, read, and acted on? In terms of action, would the political poet hope his or her poetry inspires not only more poetry writing, but the actual seeds of genius by which truly transformative politics might emerge?

Kant's political aesthetic opens to door to a grand form of anarchy wherein each individual endowed with an innate freedom to choose, be master of that choice, and not impose on the innate freedom of another is allowed to cultivate tastes which promote the freedom necessary to reproduce the pure productive capacities of nature. It is a misreading to construe the “The Categorical Imperative” as simply a doctrine of happiness wherein whatever makes the most good is the best. Kant's rights and his Right are instead definitions of a radical individual 
anarchy which becomes a collective and universal anarchy. After you steal my milk I may make another choice that has the potential to provide me with original experience wherein I may realize I didn’t really want milk anyway. That choice may have been unfree, and in fact I may realize that milk was the last thing on my mind. Why I went to store, what I was truly after and what I expected to feel, was the pleasure of exchanging legal tender for goods in an abstraction that would fracture the light just right.

\section{Works Cited}

Kant, Immanuel. The Metaphysics of Morals Trans. Mary J. Gregor and Roger J. Sullivan. Cambridge MA, Cambridge UP, 1996.

Kant, Immanuel. The Critique of Judgment Trans. Werner Pluhar. Indianapolis: Hackett,1987. Ripstein, Arthur. Force and Freedom. Cambridge, MA: Harvard UP, 2009. 